\title{
Silicate as regulating nutrient in phytoplankton competition
}

\author{
J. K. Egge, D. L. Aksnes \\ Department of Fisheries and Marine Biology, University oí Bergen, Heyteknologisenteret, N-5020 Bergen, Norway
}

\begin{abstract}
The development of phytoplankton communities was studied in floating enclosures. The enclosures were supplied with either surface water or water from $40 \mathrm{~m}$ depth. Nutrients with or without silicate were added in some of the experiments, while others recieved no artificial fertilization. It is shown that diatom dominance occurred irrespective of season if silicate concentration exceeded a threshold of approximately $2 \mu \mathrm{M}$. Flagellate dominance changed to diatom dominance within a few days after nutrient addition resulting in silicate concentrations above this threshold. Dominance of Phaeocystis sp. appeared on several occasions after the bloom of another species, but never at high silicate concentrations. The success of the diatom group seemed to be due to a high inherent growth rate at non-limiting silicate concentrations. Calculations indicated that the inherent growth rate for the diatom group had to be 5 to $50 \%$ higher than for the flagellate group in order to explain the outcome of our experiments.
\end{abstract}

\section{INTRODUCTION}

Human activities have increased the input of nitrogen and phosphorus nutrients to estuarine and coastal waters. Eutrophication and construction of artificial lakes, however, have led to decreased silicate input into the sea (Bennekom \& Salomons 1981). Furthermore, nitrogen and phosphorus are recycled more rapidly in the water column than is silicon. Thus, along with increased eutrophication in coastal areas, increased N:Si and P:Si nutrient ratios should be expected. As postulated by Officer \& Ryther (1980), a change in the nutrient composition should also affect the phytoplankton composition. According to Smayda (1990), measurements from central North Sea and Elbe-influenced water masses show significant increases in nitrate and phosphorus in recent decades, while silicate is constant or decreasing. Over the same period, the biomass of flagellates has increased by a factor of 6 to 16 while the biomass of diatoms has been constant or decreasing.

When environmental quality is reduced as a result of altered phytoplankton composition, rather than by biomass, a sound strategy may be to modify the nutrient composition rather than to reduce the magnitude of the discharge. This assumes, however, that the influence of nutrient composition on phytoplankton composition is predictable. As postulated by Officer \& Ryther (1980) it is conceivable that the $\mathrm{N}$ : Si ratio influences the composition of phytoplankton as phytoplankton communities may be divided into 2 basic categories: those dominated by diatoms and those dominated by flagellates or non-diatomaceous forms. Growth of diatoms depends on the presence of silicate while growth of the non-diatomaceous forms normally does not. Officer \& Ryther (1980) point out that flagellate communities are often associated with undesirable effects of eutrophication while diatoms are not.

The present paper reports on the effect of silicate on phytoplankton composition in 14 mesocosm experiments. Experiments were conducted in spring, summer and autumn when quite different environmental forces were acting. Despite this environmental variability, our data indicate that diatoms dominate as long as silicate concentration is held above $2 \mu \mathrm{M}$.

\section{MATERIALS AND METHODS}

Four experiments with and without silicate addition. The enclosure experiments were carried out in the period April to July 1988 in Bergen, Norway. The enclosures were $4 \mathrm{~m}$ deep plastic bags with a volume of $11 \mathrm{~m}^{3}$ and $90 \%$ light penetration (Fig. 1, Table 1). Enclosures 1 and 2 (E1 and E2) were supplied by water from $40 \mathrm{~m}$ depth while $\mathrm{E} 3$ and $\mathrm{E} 4$ were supplied with 

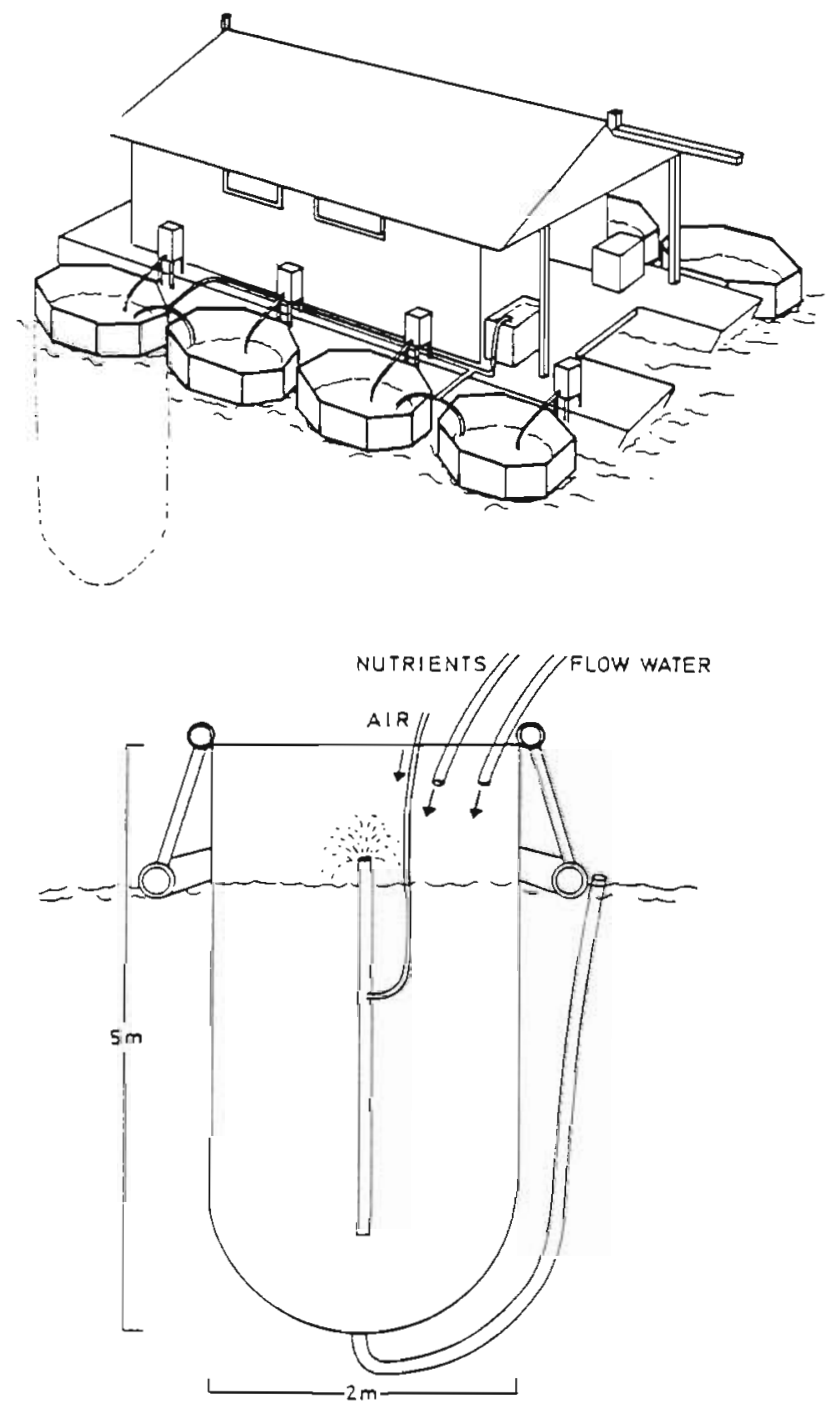

Fig. 1 The floating laboratory with the sea enclosures

surface water (from $1 \mathrm{~m}$ depth). Homogeneous watermasses within the enclosures were ensured by pumping water from the bottom of the bag to the surface at a rate of $40 \mathrm{I} \mathrm{min}^{-1}$. Nitrate and phosphate were added initially to all 4 enclosures. E2 and E4 were supplied with silicate while E1 and E3 were not. The water from $40 \mathrm{~m}$ (E1 and E2) contained, on average, 10.4, 1.0 and 8.6 uM nitrate, phosphate and silicate, while the surface water was nutrient depleted with average values of $0.3,0.06$ and $0.6 \mu \mathrm{M}$ respectively. The enclosures were grown as batch cultures for about 1 wk. Inflow of water (from 1 or $40 \mathrm{~m}$ ) was then initiated and the cultures run continuously with an average water renewal of $30 \% \mathrm{~d}^{-1}$ during the experimental period. Nitrate, phosphate and silicate (E2 and E4), or just nitrate and phosphate (E1 and E3), were added to the enclosures every second day (after sampling) during the rest of the experimental period ( $26 \mathrm{~d}$ ). Each nutrient dose corresponded to an instantaneous final concentration of about $5.5 \mu \mathrm{M}$ nitrate, $1.5 \mu \mathrm{M}$ phosphate and $6 \mu \mathrm{M}$ silicate within the enclosures.

Samples for chlorophyll (chi) a, nutrients, phytoplankton enumeration and identification were taken daily or every second day during the experiment. Samples were taken only at $1 \mathrm{~m}$ depth as the water column was homogeneous. Samples for pigment analysis were filtered through a Sartorius membrane filter $(0.45 \mu \mathrm{m})$, and analyzed fluorometrically for chl a according to Holm-Hansen et al. (1965). Samples for nutrient measurements were preserved by adding chloroform, and determinations of nitrate, phosphate and silicate were performed on a Chemlab autoanalyzer. Enumeration and identification of phytoplankton were carried out on samples preserved by neutralized formalin and acid Lugol using the sedimentation method of Utermöhl (1931). Light conditions during the experiments were obtained as global radiation (MJ $\mathrm{m}^{-2}$ ) from the Radiation observatory, University of Bergen, Norway, where measurements are made continuously.

Diatom abundance versus silicate concentration. Data on diatom abundance from the above 4 experiments together with data from an additional 10 enclosure experiments (Table 2) were plotted against silicate concentration. The purposes of these experiments were diverse. Some were aimed at the study of increased primary production by artificial upwelling (Aksnes et al. 1985), others at producing suitable food for scallops (Kaartvedt et al. 1987) and at the study of succession in enclosures (Harboe 1988). The experiments were carried out in different seasons and with different nutrient input. Measurements from the first week of all experiments were excluded. In this period high nutrient concentrations prevailed due to fertilization and low total nutrient uptake occurred due to low initial phytoplankton stock. Interspecific competition was presumably low during this period and species composition reflected initial dominance rather than competition for nutrients. Altogether, we obtained 98 records on diatom dominance versus silicate concentration from the non-initial phases.

\section{RESULTS}

\section{Nutrients and biomass in E1 to E4}

At the start of the experiments, nitrate and phosphate concentrations were high in all enclosures (Fig. 2). E2 and E4 also had high initial silicate concentrations. E1 was supplied with deep water containing about $8 \mu \mathrm{M}$ silicate, while E3 was supplied with silicate-exhausted surface water. Thus, the difference in initial silicate 
Table 1. Four $12 \mathrm{~m}^{3}$ enclosure experiments conducted in 1988. Depth of water intake, artificial nutrient addition ( $P_{i}$ phosphate, $N_{;}$ nitrate, Si; silicate). mean temperature and global radiation during the experiments are indicated. Dominant species of the seedling water masses (") are given together with species dominating after 1 wk and during the rest of the experimental period. Names are given in order of appearance

\begin{tabular}{|c|c|c|c|c|c|c|}
\hline Enclosure & $\begin{array}{l}\text { Water } \\
\text { intake }\end{array}$ & Period & $\begin{array}{c}\text { Artificial } \\
\text { fertilization }\end{array}$ & $\begin{array}{c}\text { Temp. } \\
\left({ }^{\circ} \mathrm{C}\right)\end{array}$ & $\begin{array}{c}\text { Global } \\
\text { radiation } \\
\left(\mathrm{MJ} \mathrm{m}^{-2} \mathrm{~d}^{-1}\right)\end{array}$ & Dominant species \\
\hline E1 & $40 \mathrm{~m}$ & $20 \mathrm{Apr}-15$ May & $N, P$ & 7.9 & 14.6 & $\begin{array}{l}\text { - Flagellates indet. } \\
\text { Skeletonema costatum } \\
\text { Phaeocystis sp. }\end{array}$ \\
\hline $\mathrm{E} 2$ & $40 \mathrm{~m}$ & 30 Jun-24 Jul & $N, P, S i$ & 14.2 & 12.6 & $\begin{array}{l}\text { Skeletonema costatum } \\
\text { Skeletonema costatum } \\
\text { Chaetoceros } \mathrm{sp} .\end{array}$ \\
\hline E3 & $1 \mathrm{~m}$ & 30 Jun-24 Aug & $N, P$ & 14.2 & 12.6 & $\begin{array}{l}\text { - Skeletonema costatum } \\
\text { Emiliania huxleyi } \\
\text { Phaeocystis sp. }\end{array}$ \\
\hline E4 & $1 \mathrm{~m}$ & 8 Jul-1 Aug & $\mathrm{N}, \mathrm{P}, \mathrm{Si}$ & 15.8 & 12.5 & $\begin{array}{l}\text { - Flagellates indet. } \\
\text { Skeletonema costatum } \\
\text { Chaetoceros sp. } \\
\text { Nitszschia delicatissima }\end{array}$ \\
\hline
\end{tabular}

Table 2. Experiments conducted in 1983 (Aksnes et al. 1985), 1986 (Harboe 1988), 1987 and 1988 (Egge unpubl.). Depth of water intake, indication of artificial nutrient addition ( $\mathrm{P}$; phosphate, $\mathrm{N}$; nitrate, Si; silicate), mean dilution rate, mean temperature, mean global radiation, and dominant species (>50\% of total cell numbers) are given. "Dilution rate $(0$ to $100 \%)$ was automatically controlled by the chlorophyll content in the enclosures. All experiments were mixed by airlift (Fig. 1), except the two conducted in 1983

\begin{tabular}{|c|c|c|c|c|c|c|}
\hline Time & $\begin{array}{l}\text { Water } \\
\text { intake }\end{array}$ & $\begin{array}{c}\text { Artificial } \\
\text { fertilization }\end{array}$ & $\begin{array}{c}\text { Dilution rate } \\
(\%)\end{array}$ & $\begin{array}{l}\text { Temp } \\
\left({ }^{\circ} \mathrm{C}\right)\end{array}$ & $\begin{array}{l}\text { Global radiation } \\
\left(\mathrm{MJ} \mathrm{m}^{-2} \mathrm{~d}^{-1}\right)\end{array}$ & Dominant species \\
\hline 1983 Jul & $\begin{array}{c}34 \mathrm{~m} \\
\& 0.5 \mathrm{~m}\end{array}$ & - & 8 & 12.4 & 16.8 & $\begin{array}{l}\text { Chaetoceros compressus } \\
\text { Leptocylindrus danicus }\end{array}$ \\
\hline $1983 \mathrm{Jul}$ & $\begin{array}{c}34 \mathrm{~m} \\
\& 0.5 \mathrm{~m}\end{array}$ & - & 4 & 12.4 & 16.8 & $\begin{array}{l}\text { Chaetoceros compressus } \\
\text { Leptocylindrus danicus }\end{array}$ \\
\hline $1986 \mathrm{Apr}$ & $40 \mathrm{~m}$ & $N, P$ & 23 & 8.2 & 13.1 & $\begin{array}{l}\text { Phaeocystis pouchetii } \\
\text { Skeletonema costatum }\end{array}$ \\
\hline $1986 \mathrm{Apr}$ & $40 \mathrm{~m}$ & $N, P$ & 23 & 8.2 & 13.1 & $\begin{array}{l}\text { Phaeocystis pouchetii } \\
\text { Skeletonema costatum }\end{array}$ \\
\hline $1986 \mathrm{Apr}$ & $\begin{array}{c}40 \mathrm{~m} \\
\& 0.5 \mathrm{~m}\end{array}$ & $N, P$ & 23 & 8.2 & 13.1 & Phaeocystis pouchetii \\
\hline $1986 \mathrm{Apr}$ & $\begin{array}{c}40 \mathrm{~m} \\
\& 0.5 \mathrm{~m}\end{array}$ & N, P & 23 & 8.2 & 13.1 & Phaeocystis pouchetii \\
\hline 1987 Jun & $40 \mathrm{~m}$ & $N, P$ & " & & 14.2 & Flagellates indet. \\
\hline 1987 Sep & $40 \mathrm{~m}$ & $N, P$ & $\cdot$ & 12.8 & 7.2 & Flagellates indet. \\
\hline $1988 \mathrm{Apr}$ & $40 \mathrm{~m}$ & $\mathrm{~N}, \mathrm{P}, \mathrm{Si}$ & 30 & 8.7 & 15.5 & Skeletonema costatum \\
\hline 1988 Sep & $40 \mathrm{~m}$ & N, P, Si & 30 & 17.0 & 5.4 & Skeletonema costatum \\
\hline
\end{tabular}

concentrations in $E 1$ and $E 3$ reflects the composition in 2 different water masses.

Nitrate became almost exhausted in all experiments (Fig. 2). Despite a daily nitrate-supply, nitrate concentrations fell below $0.5 \mu \mathrm{M}$ and nitrate probably became limiting. Phosphate concentrations were always higher than $0.6 \mu \mathrm{M}$ and were probably not limiting. In $\mathrm{E} 1$, silicate concentrations fell below $2 \mu \mathrm{M}$ after the sixth day, E2 had no values below $3.2 \mu \mathrm{M}, \mathrm{E} 3$ had no values higher than $0.6 \mu \mathrm{M}$, and the concentrations in E4 were higher than $2 \mu \mathrm{M}$ except for the last $5 \mathrm{~d}$.

At the beginning of the experiments, phytoplankton biomass was lower than $2 \mathrm{mg}$ chl $a \mathrm{~m}^{-3}$ in all 4 enclosures (Fig. 3). Highest chl a concentrations were observed in the enclosures with artificial silicate addition. Here average values during the experimental period were 49.9 (E2) and 31.7 (E4) $\mathrm{mg}$ chl a m $\mathrm{m}^{-3}$, while corresponding values were 24.5 (E1) and 14.6 (E3) $\mathrm{mg}$ 


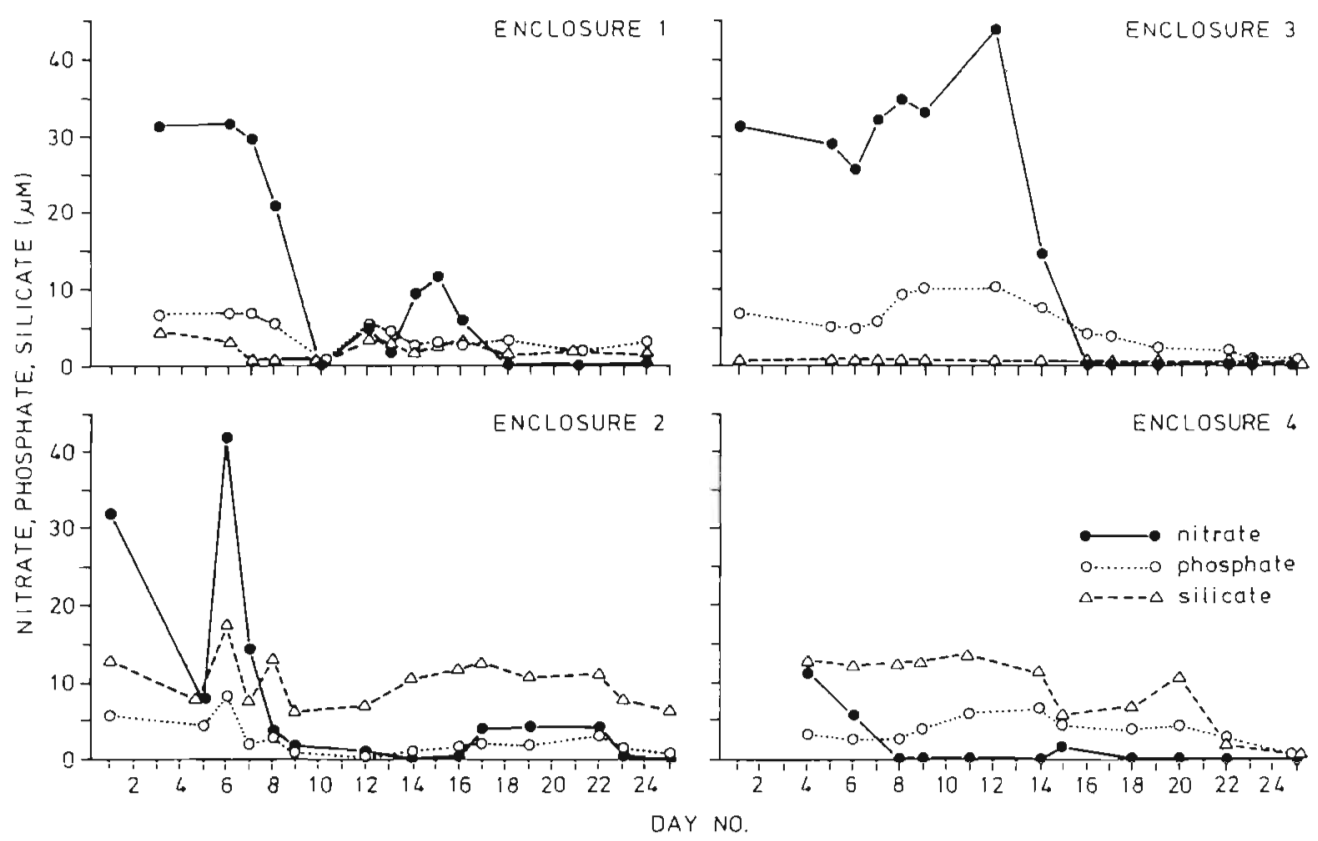

Fig. 2. Nitrate, inorganic phosphate and nitrate concentrations during the 4 enclosure experiments in 1988 (E1 and E3 without artificial silicate addition, E2 and E4 with artificial silicate addition. E1 and E2 also received some silicate through the $40 \mathrm{~m}$ depth water supply)

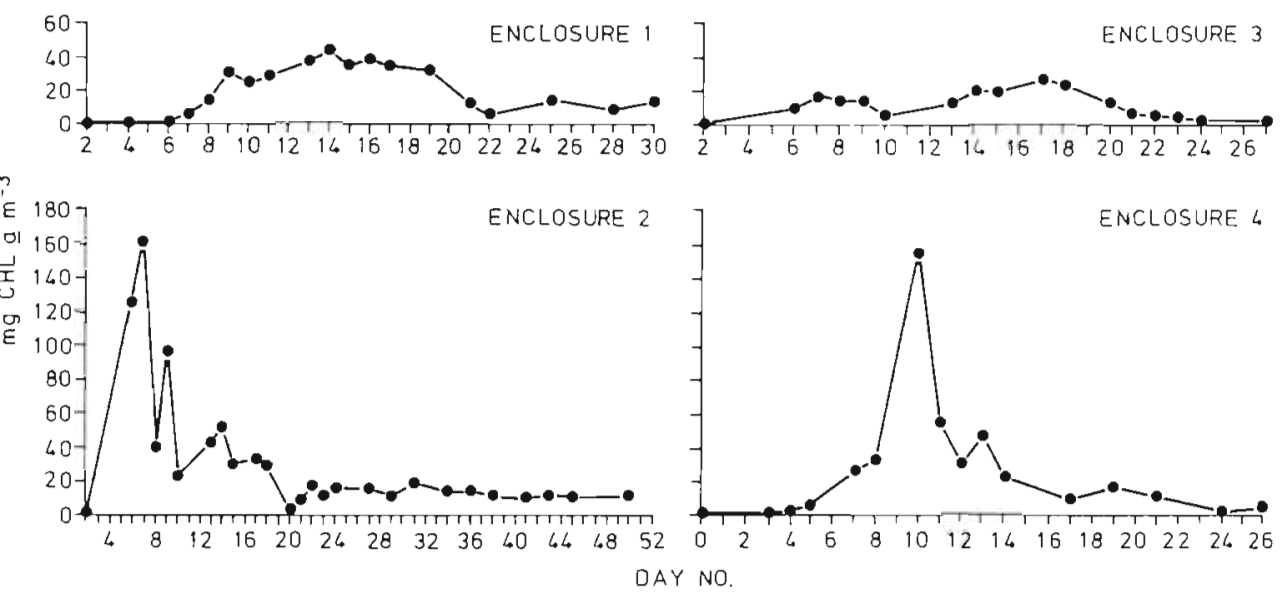

Fig. 3. Chlorophyll a concentration during the 4 enclosure experiments in 1988 (E1 and E3 without artificial silicate addition, E2 and E4 with artificial. silicate addition. E1 and E2 also received some silicate through the $40 \mathrm{~m}$ depth water supply)

chl a $\mathrm{m}^{-3}$ in the 2 enclosures without artificial silicate fertilization (Table 1). E1 received some additional silicate with the deep water and this may explain the higher chl a content in this enclosure when compared to E3

\section{Species dominance in E1 to E4}

Water from $40 \mathrm{~m}$ depth supplied with $\mathrm{N}$ and $\mathrm{P}$ (E1). The initial phytoplankton community of E1 was dominated by diatoms, mainly skeletonema costatum (Grev.) Cleve (Table 1, Fig. 4). The highest concen- tration of this species was $35 \times 10^{6}$ cells $\mathrm{I}^{-1}$. Silicate, which had initial concentration above $4 \mu \mathrm{M}$, decreased throughout the experiment and from Day 7 concentrations fell below $1 \mu \mathrm{M}$. At this time Phaeocystis sp. appeared, and constituted 6 to $64 \%$ of the total cell number for the rest of the experiment (Fig. 4). Phaeocystis colonies $\ll 2 \mathrm{~mm}$ were lobe-formed, indicating that the species was $P$. pouchetii. A temperature of $14^{\circ} \mathrm{C}$ has been reported as the upper temperature limit for $P$. pouchetii, while in E3, where Phaeocystis also dominated, the temperature was in the range 14 to $16{ }^{\circ} \mathrm{C}$. This range has been reported to be the temperature optimum for $P$. globosa (Jahnke \& Baumann 1987). 

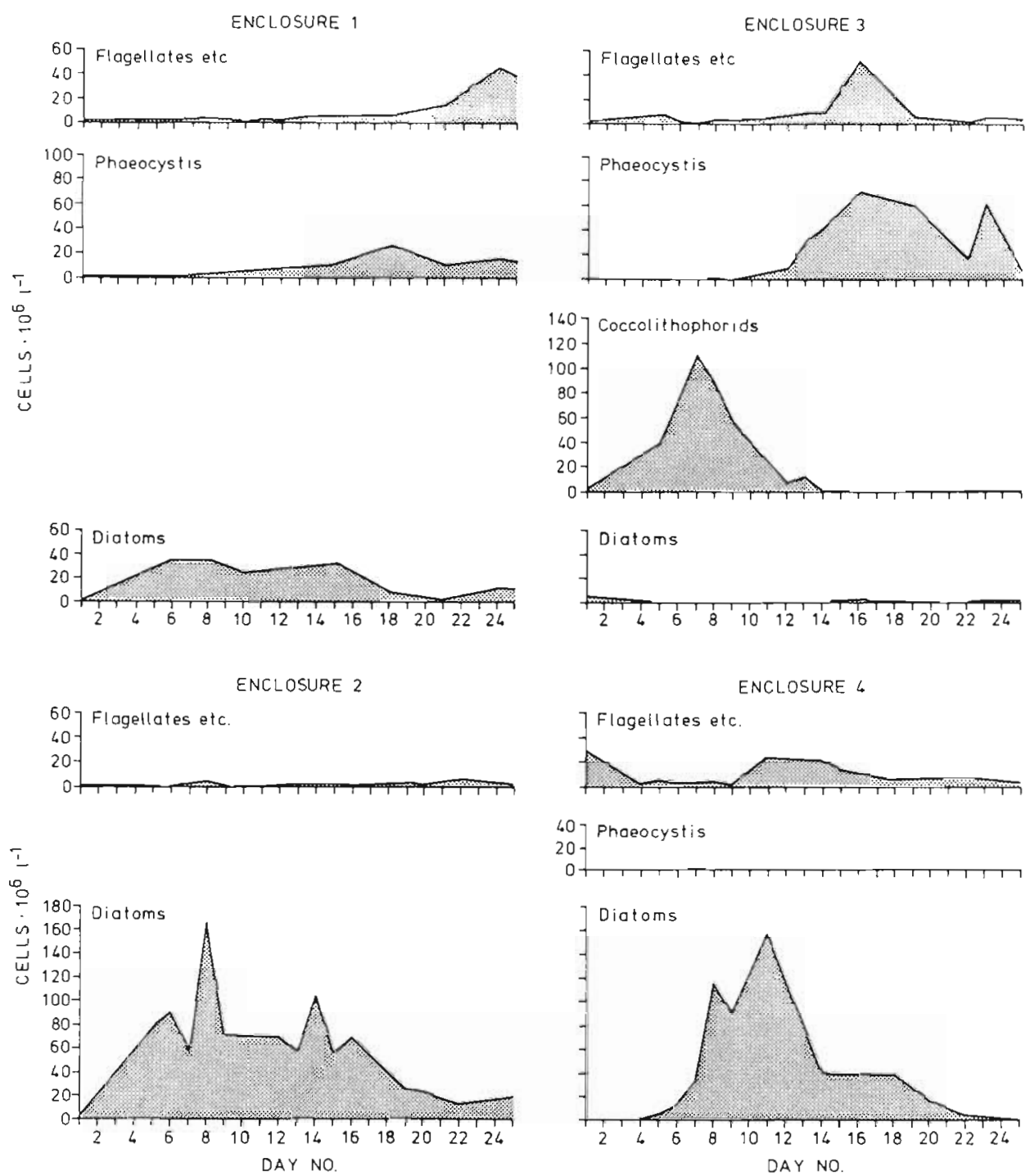

Fig. 4. Taxonomical composition during the 4 enclosure experiments in 1988 ( $E 1$ and E3 without artificial silicate addition, E2 and E4 with artificial silicate addition. E1 and E2 also received some silicate through the $40 \mathrm{~m}$ depth water supply)

Accordingly, we prefer to use the term Phaeocystis sp. in this report. S. costatum was never entirely outcompeted by Phaeocystis sp., and remained in low numbers throughout the experiment. After Day 21 small unidentified flagellates dominated the phytoplankton assemblage.

Water from $40 \mathrm{~m}$ depth supplied with $\mathrm{N}, \mathrm{P}$ and $\mathrm{Si}$ (E2). Diatoms dominated E2 during the entire experimental period (Fig. 4). Silicate concentrations were high, varying between 3 and $10 \mu \mathrm{M}$. The initial concentration of Skeletonema costatum was $1.88 \times 10^{6}$ cells $1^{-1}$ and the highest number was reached on Day 8 with $163 \times 10^{6}$ cells $1^{-1}$. S. costatum was replaced by small Chaetoceros spp. which dominated until the termination of this experiment after $52 \mathrm{~d}$ (not shown in Figs. 2 , $3 \& 4$ ). The maximum concentration of the latter species was $39 \times 10^{6}$ cells $1^{-1}$.
Water from $1 \mathrm{~m}$ depth supplied with $\mathrm{N}$ and $\mathrm{P}$ (E3). The initial community of E3 was dominated by Skeletonema costatum $\left(4.4 \times 10^{6}\right.$ cells $\left.1^{-1}\right)$ and Emiliania huxleyi (Lohm.) Hay \& Mohler $\left(1.8 \times 10^{6}\right.$ cells $\mathrm{l}^{-1}$ ). Phaeocystis sp. had a concentration of $0.14 \times$ $10^{6}$ cells $1^{-1}$. Silicate values were lower than $0.6 \mu \mathrm{M}$ during the experiment, and E. huxleyi outcompeted $S$. costatum. An extensive E. huxleyi bloom was observed during the next weeks with the highest cell number, $111 \times 10^{6}$ cells $1^{-1}$, occurring after $8 \mathrm{~d}$ (Fig. 4). After the decline of E huxleyi, Phaeocystis sp. became dominant for the rest of the experiment with a maximum concentration of $71 \times 10^{6} 1^{-1}$ on Day 16

Water from $1 \mathrm{~m}$ depth supplied with N, P and Si (E4). The initial phytoplankton community of E4 differed from E3 in that small unidentified flagellates dominated rather than diatoms. Low concentrations of 
Emiliania huxleyi $\left(0.7 \times 10^{6} 1^{-1}\right)$ and Phaeocystis sp. $\left(0.1 \times 10^{6} 1^{-1}\right)$ were also observed while diatoms were not found in the $10 \mathrm{ml}$ sample (which indicates a concentration of less than 100 ind. $\mathrm{l}^{-1}$ ). Despite these unfavourable initial conditions for diatoms, they dominated within a few days with a concentration of $120 \times$ $10^{6} 1^{-1}$. This increase amounts to a growth rate higher than $1.7 \mathrm{~d}^{-1}$ (corresponding to a doubling time of $10 \mathrm{~h}$ ). Diatoms remained dominant as long as silicate concentrations were high (Figs. 2 \& 4). The main diatom species were small Chaetoceros spp., Pseudonitzschia delicatissima (Cleve) Haiden, and Skeletonema costatum. At the end of the experiment, silicate and diatom concentrations dropped to low levels and flagellates became dominant.

\section{Diatom dominance versus silicate concentration}

Fig. 5 is based on the experiments listed in Tables $1 \&$ 2 and indicates that diatoms always dominate the phytoplankton at high silicate concentrations. When silicate concentrations are below approximately $2 \mu \mathrm{M}$ this dominance seems to cease. In some cases, diatom dominance was also found at concentrations below $2 \mu \mathrm{M}$. This dominance, however, was transitional and established in periods with high silicate concentrations. Diatom dominance ceased when concentrations remained below $2 \mu \mathrm{M}$.

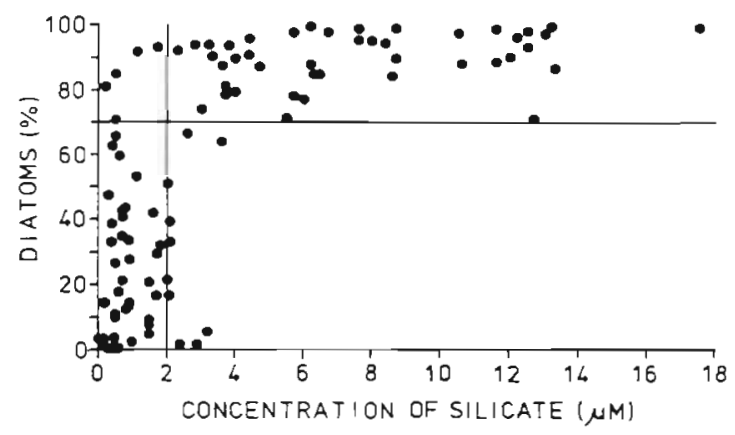

Fig. 5. Diatom dominance (given as percentage of total cell counts) versus silicate concentration. Data were obtained from the 14 enclosure experiments listed in Tables $1 \& 2$

\section{DISCUSSION}

Our experiments indicate that diatoms dominate when silicate concentration is above $2 \mu \mathrm{M}$. This seems to apply over a wide range of environmental conditions. The range of the average temperature in the experiments was 7 to $17^{\circ} \mathrm{C}$, and average surface radiation ranged from 5.42 to $16.84 \mathrm{MJ} \mathrm{m}^{-2} \mathrm{~d}^{-1}$ (unfortunately, the radiation measurements can only be approximated in terms of $\mu \mathrm{E} \mathrm{m}^{-2} \mathrm{~s}^{-1}$; the above range is within $10^{2}$ to $10^{3} \mu \mathrm{E} \mathrm{m} \mathrm{m}^{-2} \mathrm{~s}^{-1}$ during the daylight period). The water masses studied originated from the surface, from 30 to $40 \mathrm{~m}$, or from mixtures of the two. Finally, both nutrient-enriched and non-enriched experiments were carried out. The heterogeneous experimental design does not allow ordinary statistical comparisons between experiments. A balanced experimental design with respect to such factors as season, temperature, radiance, watermass, nutrient composition and nutrient loading would require an unmanageable amount of experiments. Thus, our limited number of mesocosm experiments should be interpreted more as traditional 'field' results rather than as strictly experimentally derived results. The heterogeneous environmental conditions under which the results were obtained, however, strengthen rather than weaken the conclusion about the strong influence of silicate concentration on phytoplankton species composition. The results obtained in E4 versus E3 clearly demonstrate the major influence of silicate concentration. Both experiments were run with silicate-depleted surface water. The initial community of E3 was dominated by diatoms, while E4 had initial flagellate concentrations (Emiliania huxleyi and Phaeocystis sp.) 10000 times higher than the diatom concentration. In less than 1 wk (before water renewal was initiated), however, Skeletonema costatum became dominant in E4 while the initial diatom dominance of E3 ceased. It is very unlikely that any other factor than the silicate enrichment of E4 could be responsible for the dramatic difference in species succession in the 2 enclosures.

\section{Phaeocystis sp., Emiliania huxleyi, and diatoms}

In the silicate-depleted E3, Phaeocystis sp. became dominant after an Emiliania huxleyi bloom (Fig. 4). For a short period, Phaeocystis sp. also became dominant in E1 (Fig. 4) which was moderately silicate depleted. Here, silicate was not added, but present in the deep water. In the silicate-enhanced E4, however, Phaeocystis sp. was not able to compete at any time although the environmental conditions were similar to those of E3, and Phaeocystis sp. was present at the start of the experiment.

In the North Sea it is well known that Phaeocystis sp. blooms may follow the spring diatom blooms (Gieskes \& Kraay 1977, Cadee \& Hegemann 1986, Veldhuis et al. 1986). Weisse et al. (1986) speculate whether diatoms excrete a substance which prevents Phaeocystis sp. blooming, or whether Phaeocystis sp. needs dissolved organic compounds from diatom blooms for growth stimulation. In E1, Phaeocystis sp. appeared after a bloom of diatoms and in E3 after an Emiliania huxleyi bloom. Harboe (1988) reported Phaeocystis 
pouchetii dominance after blooms of diatoms (enclosure experiments conducted in 1986; Table 2). In later unpublished experiments in 1989 Phaeocystis sp. again followed blooms of E. huxleyi. In these experiments it is not possible to conclude whether the earlier blooms influenced Phaeocystis sp. growth in any way. Nevertheless, Phaeocystis sp. has never become dominant in these experiments unless the silicate concentration has dropped to levels below $2 \mu \mathrm{M}$. It has cooccurred with diatoms at silicate concentrations slightly above $2 \mu \mathrm{M}$. This is in close agreement with Verity et al. (1988) who also found co-occurrence at such concentrations. Bennekom et al. (1975) also report that Phaeocystis blooms coincide with silicate limitation in coastal water. On the coast of northern Norway $P$. pouchetii has been reported to occur early in the spring bloom (Gaarder 1938, Heimdal 1974, Eilertsen et al. 1981). These observations, however, were not accompanied by silicate measurements, but it is likely that these were higher than $2 \mu \mathrm{M}$. Skreslet (1988) has observed positive buoyancy in $P$. pouchetti and speculate that this may facilitate a competitive advantage under light limitation and weak stratification of the water column

Emiliania huxleyi was found in the initial community in E4 (high silicate concentration), but was out-competed by diatoms. In E3 (low silicate concentration) $E$. huxleyi became dominant after 5 d. Eppley et al. (1969) report that $E$. huxleyi may compete with diatoms at low irradiance and low nitrogen concentration, but silicate conditions were not reported in their study.

\section{Possible influence of experimental conditions}

Eppley et al. (1978) found mechanical stirring to be a useful technique for manipulating the phytoplankton species composition. Pumping of water from the bottom of the bag to the surface in our experiments was done in order to make the water column homogeneous (Fig. 1). This is preferable, as sampling efforts are minimized and the results more easily interpretable. In contrast, the huge amount of data obtained in experiments involving vertical gradients (which are time-depth dependent) with physical, chemical and biological variables is extremely difficult to interpret. Furthermore, vertical gradients created in enclosure experiments are probably as artificial as the water renewal made in such experiments. Use of internal water renewal in our experiments, however, may have favoured diatoms in several ways. Resuspension of sinking individuals may have been most important. However, internal water renewal was not used in the experiments conducted in 1983 (Table 2), and diatom dominance was also observed in these experiments (Aksnes et al. 1985).
Several authors have reported mass aggregation of phytoplankton during diatom blooms (Alldredge \& Gotschalk 1989, Riebesell 1989, 1991a, b). Physical coagulation is likely to be an important process leading to flocculation of algal biomass (Jackson 1990). Although aggregates of phytoplankton were not observed in our experiments, the artificial mixing may have led to aggregation, and thereby influenced competitive relationships between species. In a mixed mesocosm experiment Riebesell (1989) found that Skeletonema costatum, which was frequently found in sediment aggregates, had a higher sinking rate than Chaetoceros spp. This may have contributed to the replacement of $S$. costatum with Chaetoceros spp. in our experiment (E2).

Most of the experiments (including E1 to E4) were operated as batch cultures the first week and thereafter as continuous cultures (see 'Materials and methods'). Hence, our results probably depend less on the initial conditions of the enclosures (data from the batch period are excluded in Fig. 5) than if the experiments were run entirely as batch cultures. Water renewal allows 'immigrating' species to compete with the established species, but under a nutrient regime controlled mainly by the artificial fertilization. The water renewal, however, also introduces a cell removal or 'mortality' factor influencing the net growth rate of the species. Theoretically, such mortality should move the growth isoclines in a resource (i.e. nutrients) space away from the resource axis as demonstrated by Tilman et al. (1982, Fig. 1D, p. 352). Although the dilution-mediated mortality, presumably, was the same for all species (at least in the stirred experiments), dilution rate may have altered the relative competitive ability among species as demonstrated by Mickelson et al. (1979) and De Pauw et al. (1983). At the extreme, species having a growth rate below the dilution rate would experience a negative realized growth despite other favourable environmental conditions. The external water renewal in E1 to E4 was about $30 \%$, while the experiments listed in Table 2 had renewal rates in the range 4 to $100 \% \mathrm{~d}^{-1}$ (Table 2 ). Due to the many factors involved, however, our data are not suitable for assessing possible influences of the dilution rate on competitive relationships between flagellates and diatoms. It is possible that the critical concentration, interpreted as $2 \mu \mathrm{M}$ silicate on the basis of our experiments (Fig. 5), depends on the actual dilution rate (external renewal) and perhaps also on the degree of stirring (internal renewal)

\section{Considerations on the success of diatoms}

The observed conditional competitive superiority of diatoms (Fig. 5) is in accordance with the extensive review of Furnas (1990) on growth rates in phytoplank- 
ton. He concludes that there appears to be a broad dichotomy between the growth potential of diatom species and non-diatoms, with the highest growth potential among the diatoms. He reports that maximum in situ doubling rates between 2 and $4 \mathrm{~d}^{-1}$ have repeatedly been measured for diatoms, and that maximum growth rates for dinoflagellate, microflagellate and eukaryotic non-motile ultraplankton species or assemblages are generally below $2.5 \mathrm{~d}^{-1}$ When silicate concentration becomes limiting, however, the potential growth cannot be realized. The realized growth rate $\left(\mu_{d}\right)$ for diatoms may then be expressed:

$$
\mu_{\mathrm{d}}=\mu_{\mathrm{d}-\max } S /\left(K_{\mathrm{s}}+S\right)
$$

where $K_{\mathrm{s}}$ is the half-saturation constant for growth rate; and $\mu_{\mathrm{d}-m a x}$ is the maximum growth rate under nonlimiting silicate concentration (S) conditions. Our experiments indicate that diatoms, as a group, were outcompeted by the 'flagellate group' at silicate concentrations below a threshold of about $2 \mu \mathrm{M}$ (Fig. 5). Then, we may postulate that the maximum flagellate growth rate $\left(\mu_{\mathrm{f}-\mathrm{max}}\right)$, which is assumed not to be influenced by silicate concentration, equals the realized diatom growth rate at $2 \mu \mathrm{M}$ silicate

$$
\begin{gathered}
\mu_{\mathrm{f}-\max }=\mu_{\mathrm{d}}=\mu_{\mathrm{d}-\max } 2 /\left(K_{\mathrm{s}}+2\right) \\
\text { or } \mu_{\mathrm{d}-\max } / \mu_{\mathrm{f}-\max }=\left(K_{\mathrm{s}}+2\right) / 2
\end{gathered}
$$

Here, it is assumed that the flagellates are not seriously limited by other factors, or more precisely that diatoms and flagellates are equally limited by all other factors except silicate. Inserting half-saturation constants for silicate-limited growth in the range 0.1 to $1 \mu \mathrm{M}$ (Paasche 1980), it follows that a 5 to $50 \%$ higher inherent growth for the diatom group may explain the outcome of our experiments (Fig. 5).

Several authors have speculated on why diatoms can grow at higher rates than other algae, and Thomas et al. (1978) stated that there must be reasons for the success of diatoms, but that these remain obscure. They hypothesized that diatoms might have a better ability to utilize low nitrogenous nutrient levels, i.e. that diatoms have lower half-saturation values $\left(K_{\mathrm{s}}\right)$ for nitrate and ammonium uptake. They pointed out, however, that this trend could not be statistically established on the basis of measured $K_{\mathrm{s}}$ values (Eppley et al. 1969). According to the nutrient uptake model of Aksnes \& Egge (1991) (and references therein), however, the $K_{s}$ value should not be taken as a measure of nutrient uptake efficiency. The affinity $(\alpha)$ is the significant uptake parameter at low nutrient concentrations, and it depends on both the maximum uptake rate and the half saturation parameter.

A higher photosynthetic capacity due to a higher chlorophyll content in diatoms (Langdon 1988) is also believed to be responsible for the higher inherent growth rate observed in diatoms. In our experiments too, the Si-fertilized bags (E2 and E4) had a much higher chlorophyll content than the two without artificial Si fertilization (E1 and E3). This undoubtedly contributed to a higher potential growth rate in these bags being dominated by diatoms. Our experiments, however, can hardly throw light onto mechanisms behind the success of diatoms. On the other hand, the important role of silicate concentration as a factor in competition is clearly demonstrated by the enclosure experiments, and gives strong support for Officer \& Ryther's (1980) concern about the importance of silicon in marine euthrophication. Parsons et al. (1978) suggested a diatom 'corridor' (with respect to light and nutrient conditions) of maximum growth leading to diatom blooms in the ocean. Our experiments indicate that this corridor of diatom dominance may be generated under a wide range of environmental conditions as long as the silicate concentration is above approximately 2 uiv. This is probably due to a higher maximum growth rate in diatoms being realized at non-limiting silicate concentrations.

Acknowledgements. We thank $\mathrm{T}$ Harboe for access to the data from his cand scient. thesis. Furthermore, we thank P. H. Enckell, D. Evens, B. R. Heimdal, E. Paasche and 3 unknown referees for valuable comments on earlier versions. A. Aadnesen for the nutrient analyses, and $E$. Holm for drawing the figures. Financial support was given by the Royal Norwegian Council for Scientific and Industrial Research (NTNF) and the Norwegian Fisheries Research Council (NFFR)

\section{LITERATURE CITED}

Aksnes, D. L., Egge, J. K. (1991). A theoretical model for nutrient uptake in phytoplankton. Mar. Ecol. Prog. Ser 70: $65-72$

Aksnes, D. L., Magnesen, T., Lie, U. (1985). Nutrient enrichment experiments in plastic cylinders and the implications of enhanced primary production in Lindåspollene, Western Norway. Sarsia 70: 45-58

Alldredge, A. L., Gotschalk, C. C. (1989). Direct observations of the mass flocculation of diatom blooms: characteristics, settling velocities and formation of diatom aggregates. Deep Sea Res. 36: 159-171

Bennekom, A. J. van, Gieskes, W. W. C., Tijssen, S. B. (1975) Eutrophication of Dutch coastal waters. Proc. R. Soc. Lond. (B): $359-374$

Bennekom, A. J. van, Salomons, W. (1981). Pathways of nutrients and organic matter from land through rivers. In: SCOR Working Group No. 46, Proc. of Review Workshop. River inputs to ocean systems. United Nations, New York. p. $33-51$

Cadee, G. C., Hegeman, J. (1986). Seasonal and annual variation in Phaeocystis pouchetii (Haptophyceae) in the westernmost inlet at the Wadden Sea during the 1973 to 1985 period. Neth. J. Sea Res. 20: 29-36

De Pauw, N., Verboven, J., Claus, C. (1983). Aquacultural Engineering 2: 27-47 
Eilertsen, H. C., Schei, B., Taasen, J. P. (1981). Investigations on the plankton community of Balsfjorden, northern Norway. The phytoplankton 1976-1978. Abundance, species composition, and succession. Sarsia 66: 129-141

Eppley, R. W., Rogers, J. N., McCarthy, J. J. (1969). Half saturation constants for uptake of nitrate and ammonium by marine phytoplankton. Limnol. Oceanogr 14: 912-920

Eppley, R. W., Koeller, P., Wallace, T W. Jr (1978). Stirring influences the phytoplankton species composition withın enclosed columns of coastal sea water J. exp. mar Biol. Ecol. 32: 219-239

Furnas, M. J. (1990). In situ growth rates of marine phytoplankton: approaches to measurement, community and species growth rate. J. Plankton Res. 12: 1117-1151

Gaarder, K. R. (1938). Phytoplankton studies from the Tromse district 1930-3. Tromso Mus. Årsh. 55: 1-159

Gieskes, W. W., Kraay, G. W. (1977). Continuous plankton records: changes in the plankton of the North Sea and its eutrophic Southern Bright from 1948 to 1975. Neth. J. Sea Res. 9: 166-196

Harboe, T (1988). Produksjon og suksesjon i eutrofierte plastinnhegninger nedsenket i sjø. Cand. scient. thesis, Univ. of Bergen

Heimdal, B. R. (1974). Composition and abundance of phytoplankton in the Ullsfjord area, North Norway. Astarte 7: $17-42$

Holm-Hansen, O., Lorenzen, C. J., Holmes, R. W., Strickland, J. D. H. (1965). Fluorometric determination of chlorophyll. J. Cons. perm. int. Explor. Mer 30: 3-15

Jahnke, J., Baumann, M. E. M. (1987). Differentiation between Phaeocystis pouchetii (Har.) Lagerheim and Phaeocystis globosa Scherffel. I. Colony shapes and temperature tolerance. Hydrobiol. Bull. 21. 141-147

Jackson, G. A. (1990). A model of the formation of marine algal flocs by physical coagulation processes. Deep Sea Res. 31. $67-76$

Kaartvedt, S., Aksnes, D. L., Egge, J. K. (1987). Effect of light on the vertical distribution of Pecten maximus larvae. Mar. Ecol. Prog. Ser. 40: 195-197

Langdon, C. (1988). On the causes of interspecific differences in the growth-irradiance relationship for phytoplankton. II. A general review. J. Plankton Res. 10: 1291-1312

Mickelson, M. J., Maske, H., Dugdale, R. C. (1979). Nutrientdetermined dominance in multispecies chemostat cultures of diatoms. Limnol. Oceanogr. 24: 298-315

This article was submitted to the editor
Officer, C. B., Ryther, J. H. (1980). The possible importance of silicon in marine eutrophication. Mar. Ecol. Prog. Ser 3 : 83-91

Parsons, T R., Harrison, P. T., Waters, R. (1978). An experimental simulation of change in diatom and flagellate blooms. J. exp. mar. Biol. Ecol. 32: 285-295

Paasche, E. (1980). Silicon. In: Morris, I. (ed.) The physiological ecology of phytoplankton. Blackwell Scientific Publications, Oxford, p. 259-284

Riebesell, U. (1989). Comparison of sinking and sedimentation rate measurements in a diatom winter/spring bloom. Mar. Ecol. Prog. Ser 54: 109-119

Riebesell, U. (1991a). Particle aggregation during a diatom bloom. I. Physical aspects. Mar. Ecol. Prog. Ser. 69: 273-280

Riebesell, U. (1991b). Particle aggregation during a diatom bloom. II. Biological aspects. Mar Ecol. Prog. Ser. 69: 281-291

Skreslet, S. (1988). Buyoancy in Phaeocystis pouchetii (Hariot) Lagerheim. J. exp. mar. Biol. Ecol. 119: 157-166

Smayda, T. J. (1990). Novel and nuisance phytoplankton blooms in the sea: evidence for a global epidemic. In: Graneli, E., Sundström, B., Edler, L., Anderson, D. (eds.) Toxic marine phytoplankton. Elsevier Science Publishing Co. New York, p. 29-40

Thomas, W. A., Dodson, A. N., Reid, F. M. H. (1978). Diatom productivity compared to other algae in natural marine phytoplankton assemblages. J. Phycol 14: 250-253

Tilman, D., Kilham, S. S., Kilham, P. (1982). Phytoplankton community ecology the role of limiting nutrients. Annls Rev. Ecol. Syst., 13: 349-372

Utermöhl, H. (1931). Neue Wege in der quantitativen Erfassung des Planktons. (Mit besonderer Berücksichtigung des Ultraplanktons). Verh. int. Verein. theor angew. Limnol. 5: $567-596$

Veldhuis, M. J. W., Colyn, F., Venekamp, A. H. (1986). The spring bloom of Phaeocystis (Haptophyceae) in Dutch coastal water. Neth. J. Sea Res. 20:37-48

Verity, P. G., Villareal, T A., Smàyda, T J. (1988). Ecological investigations of blooms of colonial Phaeocystis pouchetii. I. Abundance, biochemical composition, and metabolic rates. J. Plankton Res. 10: 219-248

Weisse, T., Grimm, N., Hickel, W., Martens, P. (1986). Dynamics of Phaeocystis pouchetii blooms in the Wadden Sea of Sylt (German Bight, North Sea). Estuar. coast. Shelf Sci. 23: 171-182

Manuscript first received: January 15, 1992

Revised version accepted: May 7, 1992 